\title{
Elaborating Appropriate Models of the Sustainable Financing Instrument in Public Private Partnerships (PPP) In Infrastructure Projects
}

\author{
Dr. Prawitra Thalib, S.H., M.H. ${ }^{a}$, Faizal Kurniawan, S.H., M.H., LL.M. ${ }^{\mathrm{a}}$, Erni Agustin, S.H., \\ LL.M. ${ }^{\mathrm{a}}$, Rizky Amalia, S.H., M.H. ${ }^{\mathrm{a}}$
}

${ }^{a}$ Fakultas Hukum Universitas Airlangga, Kampus B Jl. Dharmawangsa Dalam, Surabaya, 60286, Indonesia

\begin{abstract}
One alternative to accelerate infrastructure development in Indonesia is by involving the private sectors in the financing and development. In principle, Public Private Partnerships (PPP) can be classified into two, namely: a partnership project which idea came from the initiation of the government (solicited) and partnership project which idea came from the initiation of the business entities (unsolicited). To facilitate the implementation of the Public Private Partnership (PPP), the financing instruments that exist currently may be used to support the implementation of the Public Private Partnership (PPP). The importance of involving a third party other than investor and the government is related to the fulfillment of capital requirements and risks sharing in the event of loss. Although the rules clearly have been enacted, the infrastructure projects in Public Private Partnership (PPP) seem less attractive to investors. One of the causes is that the capital required by investors is too great with very high risk when investment in infrastructure is slow yielding. It is important to propose the scheme of sustainable financing which may allocate the PPPs' risks proportionally.Until now, the government is too fixated with large cooperation projects with the private sectors, while the scheme offered is a Build-Operation-Transfer (BOT) scheme. This scheme is sometimes burden the investors, because the greatest risk is in the hands of investors. Regarding the financing of the Public Private Partnership (PPP), conventional financing such as a bank guarantee or sharia financing ('kafalah') can be carried out. Two such financing can be used in the Public Private Partnership (PPP), so it will increase the interest of investors to build infrastructure using Public Private Partnership (PPP). It is because such financing can overcome the difficulties of gaining large capital and also reduce the burden of risk borne by investors.

Keywords: Public Private Partnership (PPP), Sustainable Financing, Infrastructure Development.
\end{abstract}

\section{Pendahuluan}

Investasi adalah kata kunci dalam proses percepatan pembangunan infrastruktur, yang secara rinci kegiatan tersebutdapat diwujudkan dengan menggunakan mekanisme Public Private Partnerships (PPP), melalui mekanisme ini pemerintah dapat memfasilitasi kepentingannya dan kepentingan investor secara bersamaan, ini adalah mekanisme terbaik untuk menarik investor supaya mereka dapat menggunakan teknologi dan inovasi yang mereka miliki demi kepentingan negara. Namun setiap investasi tidak hanya dibarengi dengan keuntungan, dalam hal ini ada bayang-bayang potensi risiko yang dapat menimbulkan kerugian yang dapat mengancam proses investasi. Potensi risiko tersebut tidak hanya berasal dari dalam saja (internal) namun juga dapat berasal dari luar (eksternal). Ancaman ini selalu menjadi momok tersendiri bagi para investor, oleh karenanya investor sebelum melakukan suatu investasi pasti akan melakukan suatu kajian terhadap potensi kerugian, yang mana hal ini adalah bagian dari analisis manajemen risiko yang dilakukan untuk mencegah hal-hal yang tidak diinginkan di kemudian hari. Potensi risiko ekstenal adalah di luar kendai pemerintah secara tidak langsung, hal ini dikarenakan potensi ini muncul adanya suatu minat pasar (market interest) dimana investasi tadi dilakukan, namun terhadap potensi risiko eksternal hal ini sepenuhnya menjadi kendali pemerintah sepenuhnya, dalam hal ini kestabilan pemerintah adalah kunci utama, keinginan pemerintah untuk terus menghormati apa yang telah disepakati dalam Public Private Partnerships (PPP) adalah faktor penentu tanpa hal tersbeut investasi akan menjadi tiada artinya investor akan melarikan diri dan pembangunan tidak akan berjalan secara maksimal. Keterlibatan pihak swasta ataupun pihak asing sebagai investor amatlah diperlukan dalam melakukan pembangunan jangka panjang yang berkelanjutan, sejarah telah membuktikan ketika terjadi Krisis Uganda di masa pemerintahan Idi Amin, penolakan terhadap pihak asing dalam kegaitan perekonomian Uganda telah menjadi bumerang bagi negara tersebut, tidak saja pembangunan infrastruktur menjadi terhambat, pertumbuhan sektor agraris pun menjadi stagnan, hal ini diakibatkan ketidak jelian pihak pemerintah untuk menangkap peluang yang ada dalam kegiatan investasi. Sebagaimana halnya manusia adalah zoon politicon yang membutuhkan interaksi dengan manusia yang lainnya, begitu pula dengan sautu negara yang merupakan perwujudan dari kepentingan-kepentingan politis yang membutuhkan pihak lain untuk senantiasa berkembang dan mensejahterakan rakyatnya, pemeritnah membutuhkan swasta dalam pengelolaan sumber daya yang dimilikinya sementara investor membutuhkan pemerintah untuk mengembangkan usahanya. Kondisi mutual simbiosis ini adalah kondisi yang harus diwujudkan demi pencapai keuntungan bersama antara pemerintah dan swasta, dalam hal ini Public Private Partnerships (PPP) dapat berperan seabgai instrumen untuk mewujudkan hal tersebut, namun demikian kepentingan-kepentingan yang dimuat dalam Public Private Partnerships (PPP) harus 
dilindungi secara hukum, sehingga dengan adanya kepastian hukum investor tidak akan ragu untuk menanamkan modalnya.

Salah satu langkah yang dapat dilakukan oleh investor untuk mengurangi potensi-potensi risiko yang dapat muncul dalam suatu kegiatan investasi adalah melalui uapaya untuk melibatkan pihak ketiga dalam investasi tersebut, adapun pihak ketiga yang dapat dilibatkan dalam kegaitan investasi tersebut adalah lembaga keuangan bank. Perbankan menjadi pilihan utama sebagai pihak ketiga dalam suatu investasi dikarenakan perbankan dapat memberikan jaminan bagi pemerintah supaya investor tidak mengingkari isi perjanjian atau wanprestasi dan bagi investor juga dapat menjadi jaminan bahwa pemerintah akan terus menghoirmati perjanjian yang dibuat sampai dengan berakhirnya perjanjian tersebut. Perbankan mempunyai posisi vital dalam sistem perekonomian, dampak sistemis perekonomian yang dimilikinya menjadikan industri perbankan mempunyai prestise atau kebanggan tersendiri dalam kelancaran perputaran roda bisnis dan perekonomian. Posisi strategis yang dimiliki oleh industri perbankan inilah yang harus dimanfaatkan dengan maksimal oleh investor, pengamatan yang jeli dan seksama terhadap hal tersebut akan menjadikan investor mempunyai potensi kerugian yang minim tanpa harus memangkas kepentinganya untuk mendapat keuntungan dari investasi yang dilakukan.

Public Private Partnerships (PPP) adalah kontrak kerjasama yang melibatkan pihak pemerintah dengan pihak swasta, dalam kontrak kerjasama tersebut sebagaimana kontrak-kontrak bisnis pada umumnya pasti akan menimbulkan suatu potensi keuntungan yang diikuti dengan potensi risiko, investor ketika menggunakan jasa perbankan tidak hanya mengharapkan tereliminirnya risiko internal yang muncul dari pemerintah namun lebih daripada itu juga dapat melakukan pembagian risiko kepada perbankan apabila investasi yang diwujudkan melalui Public Private Partnerships (PPP) tersebut gagal. Dalam hal ini perbankan tidak perlu takut akan dimanfaatkan oleh investor, pemerintah tidak perlu kuatir akan dijadikan alat oleh investor untuk mendapat keuntungan semaksimal mungkin, hal ini dikarenakan kunci dalam Public Private Partnerships (PPP) adalah keuntungan bagi semua pihak yang terlibat dalam kegiatan tersebut. Investor dapat meraih keuntungan yang sebesar-besarnya dalam Public Private Partnerships (PPP), namun pemerintah harus memastikan bahwa keuntungan yang diperoleh investor tersebut harus seimbang dengan hasil atau manfaat yang dirasakan bagi pemerintah dan rakyat, perbankan juga dapat meraih keuntungan dalam proses Public Private Partnerships (PPP) karena fungsi perbankan sebagai lembaga intermediasi harus tetap sustainable demi mewujudkan kelancara roda perekonomian di suatu negara, vitalnya fungsi perbakan tersebut harus dimanfaatkan secara maksimal oleh investor dan pemerintah supaya Public Private Partnerships (PPP) dapat berjalan sesuai dengan yang diharapkan.

Indonesia mempunyai sistem perbankan yang cukup kuat yang didukung dengan 6 pilar API (arsitektur perbankan Indonesia) telah menjadikan perbanakn Indonesia adalah mitra yang layak dijadikan sebagai pihak ketiga dalam Public Private Partnerships (PPP). Sistem perbankan Indonesia menganut sistem perbankan dua kamar atau dual banking system, yaitu suatu sistem perbankan yang terdiri dari dua konsep perbankan yang saling mendukung antara stu dengan yang lain yang dalam hal ini adalah perbankan konvensional dan perbankan syariah atau perbankan Islam yang juga dikenal dengan bank bebas bunga (riba free bank/RF). Kedua sistem tersebut berjalan beriringan dalam menggerakan roda perekonomian Indonesia, keduanya sama-sama mempunyai payung hukum yang jelas yaitu Undang-Undang Nomor 7 Tahun 1992 jo. Undang-Undang Nomor 10 tahun 1998 tentang Perbankan dan Undang-Undang Nomor 21 Tahun 2008 Tentang Perbankan Syariah, terlebih lagi dengan keberadaan dari Otoritas Jasa Keuangan (OJK) sebagai lembaga tertinggi pengaturan dan pengawasan lembaga keuangan yang ada di Indonesia telah menjadikan sistem perbankan Indonesia menjadi semakin solid dan liquid, hal ini tentu saja berdampal positif terhadap ilkim investasi di Indonesia[1]. melihat potensi keuntungan yang dapat diperoleh dalam kegiatan Public Private Partnerships (PPP) telah menjadikan sistem perbankan juga mempunyai mekanisme tersendiri untuk menjadi pihak dalam kegiatan tersebut, baik perbakan konvensional maupun perbankan syariah kedua sistem perbankan tersebut dapat menggunakan jasa pembiayaan yang dimiliknya untuk mendukung kelancaran pelaksanaan dari Public Private Partnerships (PPP), hal ini secara tidak langsung juga merupakan perwujudkan dari fungsi intermediasi lembaga perbankan yang harus diterapkan oleh sistem perbakan demi memperlancar pergerakan roda perekonomian, sebagaimana yang telah di tentukan dalam Undang-Undang Nomor 7 Tahun 1992 jo. Undang-Undang Nomor 10 tahun 1998 tentang Perbankan dan UndangUndang Nomor 21 Tahun 2008 Tentang Perbankan Syariah.

Untuk dapat berpartisipasi dalam kegiatan Public Private Partnerships (PPP) yang bertujuan memajukan pembangunan infrastruktur tanah air, perbankan syariah dan perbankan konvesional, masing-masing mempunyai cara tersendiri melalui produk-produk pembiayaannya, akan tetapi sekalipun demikian bank tidak akan dengan begitu mudahnya membantu pembiayaan kegiatan Public Private Partnerships (PPP) bagi investor, hal ini dikarenakan perbankan (baik yang berbasis syariah dan konvensional) keduanya sama-sama dituntut untuk menerapkan prinsip kehati-hatian (prudential principle) ketika akan menggunakan fungsi intermediasi. Semua bank tanpa terkecuali dalam melakukan kegiatan usahanya wajib menerapkan prinsip kehati-hatian (prudential principle) yang lebih lanjut dijabarkan dalam bentuk rambu-rambu kesehatan bank atau prudential standards. Prinsip kehati-hatian bank adalah kunci keberhasilan industri perbankan, sering prinsip ini hanya dikaitkan dengan masalah penyaluran dana, pandangan demikian ini keliru sebab prinsip kehati-hatian bukan diterapkan pada saat bank menjalankan kegiatan usahanya tetapi sudah diterapkan pada saat pendirian bank tersebut. Prinsip kehati-hatian dalam hal ini merupakan suatu landasan hukum yang memberikan pedoman kepada bank bagaimana melaksanakan kegiatan usahanya atas dasar asas-asas 
perbankan yang sehat, ini adalah bagian dari manajemen risiko sistem perbankan, bank dituntut untuk selalu hati-hati supaya dapat memastikan tidak adanya kerugian yang dialami bank, karena seperti yang telah dibahas sebelumnya investor dapat menggunakan jasa perbanakn untuk membagi risiko kerugia yang akan terjadi dan dalam hal ini bank harus jeli untuk membaca situasi level potensi kerugian yang mungkin akan terjadi, apabila potensi kerugian dalam suatu Public Private Partnerships (PPP) tersebut tinggi, maka bank harus menolak meberikan pembiayaan, namun sebaliknya apabila potensi kerugiannya relatif rendah maka bank dapat memberikan pembiayaan kepada investor dalam kegiatan Public Private Partnerships (PPP) yang dilakukan investor dengan pemerintah. Dalam hal ini kejelian bank amatlah diperlukan supaya dapat meminimalisisir potensi-potensi risiko yang dapat menimbulkan kerugian di kemudian hari, ini secara tidak langsung merupakan penerapan dari fungsi kehati-hatian dalam sistem perbankan Indonesia.

\section{Pembahasan}

Setiap kegiatan usaha pasti mengandung risiko begitu pula dengan Public Private Partnerships (PPP), investasi adalah bisnis yang bertujuan untuk mencari keuntungan dan setiap keuntungan pasti menimbukan risiko kerugian, hal ini tidak dapat dihindari sehingga yang terpenting bukanlah berupaya menghilangkan potensi kerugian namun yang terbaik adalah berusaha untuk meminimalisir ptensi kerugian tersebut supaya tidak terjadi di kemudian hari. Manajemen risiko memainkan peranan penting dalam pengaplikasian Public Private Partnerships (PPP), manajemen risiko harus dilakukan oleh investor, perbankan dan pemerintah tanp.a terkecuali, sehingga analisis dari manajemen risiko tersebut dapat menentukan apakah Public Private Partnerships (PPP) pelu dilaksanan atau tidak, karena jangan sampai muncul suatu kondisi dimana Public Private Partnerships (PPP) dijalankan tanpa melakukan analisis manajemen risiko terlebih dahulu. ${ }^{1}$ Setiap pihak yang terlibat dalam Public Private Partnerships (PPP) baik itu investor, pemerintah maupun perbankan harus dilindungi secara hukum, Public Private Partnerships (PPP) seabgaimana kontrak-kontrak lain pada umumnya mempunyai legal binding yang kuat yang sama kuatnya dengan undang-undang, kekuatan mengikat tersebut mewajibkan para pihak yang mengigatkan diri dalam perjanjian tersebut wajib untuk tunduk dan patuh pda pelaksanaan isi perjanjian yang telah disepakati sebelumnya, oleh karena itu dalam pemenuhan prestasi dari perjanjian tersebut jangan sampai ada pihak yang dirugikan dan jangan sampai pula menimbulkan kertugian bagi pihak lain, disinilah pentingnya mengetahui potensi risiko-risiko yang akan muncul disamping memamahi potensi keuntungan yang akan didapatkan, karena dengan mengetahui potensi risiko tersebut dapat diambil suatu tindakan apakah Public Private Partnerships (PPP) perlu untuk dilakukan atau tidak [2].

Bagi pemerintah untuk dapat meminimalisir Public Private Partnerships (PPP) maka dapat menggunakan instrumen penilaian dari perbankan, berdasarkan hasil penilaian perbankan tersebut pamerintah dapat melakukan penilaian yang pada akhirnya akan menghasilkan keputusan apakah akan tetap melanjutkan Public Private Partnerships (PPP) dengan investor tertentu atau tidak melanjutkan Public Private Partnerships (PPP) dan mencari investor lain yang layak, keterlibatan sektor perbanakn dalam Public Private Partnerships (PPP) amatlah penting karena dengan menilai keterlibatan pihak perbankan maka pemerintah dapat melakukan penilain dalam pembuatan keputusan sebelum dituangkan secara kontraktual, bank tidak akan memberikan penilaian yang tidak didasari dengan alasan yang jelas, dalam hal ini ketika bank memutuskan untuk memberikan jaminannya pada investor tentu hal tersebut didasari oleh adanya alasan yang kuat kenapa investor tersebut layak untuk di biayai dan ketika bank menolak untuk memberikan jaminannya pada investor hal ini tentu saja juga didasari oleh adanya alasan pembenar, hal ini dikarenakan selain dituntut untuk menerapkan prisip kehati-hatian dalam menjalankan fungsi intermediasinya bank juga dituntut untuk memastikan tingkat risiko kerugian dalam suatu pembiayaan supaya bank tersebut tidak mengalami kerugian, karena sebagaimana yang diketahui berdasarkan peristiwa-peristiwa yang telah terjadi, kerugian yang dialami bank dapat menimbulkan dampak sistemik yang tidak saja berimbas pada sektor jasa keuangan namun juga dapat berdampak pada sektor perekonomian lainnya, yang mana apabila hal ini terjadi maka secara otomatis akan dapat menghambat roda perekonomian yang pada puncaknya akan menimbulkan krisis ekonnomi, salah satu kegagalan bank dalam mengatasi potensi risiko yang ada dapat dilihat pada peristiwa keruntuhan Lehmann \& Brothers Bank, karena kegagalanya dalam melihat potensi risiko mortgate yang ada di Amerika Serikat, maka terpaksa bank yang berusia 150 tahun tersebut harus menghadapi kehancuran, namun kehancuran bank tersebut tidak hanya berpengaruh pada bank tersebut ataupun pada sektor perbankan saja, namun dampaknya dirasakan disegala askpek perekonomian, sektor swasta mengalami kerugian finansial yang tidak terbayangkan sebelumnya, sehingga PHK masal terjadi dimana-mana hal ini secara tidak langsung menyebabkan banyak orang harus kehilangan tempat tinggal, inilah dampak sistemik tersebut yang merambah kesegala sektor tidak hanya perbankan saja, sedemikian parahnya dampak sistemik yang dialami oleh Amreika Serikat tersebut menyebabkan Pemerintahan Barrack Obama terpaksa mengeluarkan kebijakan dana talangan atau bail out supaya damapak sistemik tersebut bisa segera dihentikan. Oleh karena begitu parahnya dampak sistemik tersebut maka industri perbankan sealalu dituntut untuk mewujudkan prinsip kehati-hatian dalam menjalanakn fungsi intermediasinya.

Tuntutan dan keharusan bagi industri perbankan untuk menggunakan prinsip kehati-hatian inilah yang harus dimanfaatkan oleh pemerintah ketika akan mengadakan Public Private Partnerships (PPP) dengan investor, supaya dikemudian hari ketika Public Private Partnerships (PPP) telah dilaksanakan tidak ada risiko-risiko yang muncul 
dikarenakan kegagalan untuk memahami integritas dari masing-masing pihak dalam Public Private Partnerships (PPP) tersebut. Sekalipun Public Private Partnerships (PPP) merupakan kerjasma yag dilakukan oleh pemerintah dan investor amatlah penting sekali untuk melibatkan bank dalam kegiatan tersebut, hal ini dilakukan pada dasarnya untuk mengatasi dua persoalan utama dalam Public Private Partnerships (PPP), yang antara lain adalah:

1. Kesulitan permodalan Public Private Partnerships (PPP)

2. Pembagian risiko kegagalan Public Private Partnerships (PPP)

Untuk menggunakan jasa industri perbankan dalam kegiatan Public Private Partnerships (PPP) ada dua sistem perbankan yang dapat digunakan yaitu perbankan konvensional dan perbankan syariah, Indonesia menganut dual banking system mengenal dua sistem perbankan tersebut, masing-masing sistemperbankan mempunyai cara tersendiri untuk dapat terlibat dalam Public Private Partnerships (PPP), namun pada prinsipnya sama yaitu sebagai penjamin investor terhadap pemerintah bahwa investor akan memenuhi kewajibannya dalam Public Private Partnerships (PPP), dan tentu saja bank tidak akan sembarangan memberikan jaminannya kerena hal ini berkaitan dengan manajemen risiko dari bank tersebut sekaligus berkaitan dengan reputasi bank apabila gagal menjamin investor. Adapun mengenai bentuk jaminan yang dapat diberikan oleh bank terhadap Public Private Partnerships (PPP) adalah:

1. Bank garansi

Pada dasarnya bank garansi adalah suatu perjanjian penanggungan atau penjaminan yang diatur dalam Pasal 1820 KUH Perdata. Istilah garansi sendiri berasal dari bahasa Inggris guarantee atau guaranty yang berarti menjamin atau jaminan. Dalam bahasa Belanda disebut dengan bortgtog. pemberian garansi dapat dilihat sebagai suatu jaminan atas hutang atau pekerjaan yang harus dilakukan oleh sesuatu pihak. Akan tetapi di sisi lain, pemberian garansi tersebut kebanyakan sebenarnya juga merupakan salah satu model pembayaran, yaitu memberikan pembayaran jika ada hutang yang tidak terbayar atau ada pekerjaan yang tidak terlaksana, jaminan dalam perjanjian garansi dimaksudkan sebagai tindakan dari pihak penjamin untuk menjamin bahwa jika investor tidak menunaikan kewajibannya, misalnya tidak membayar hutanghutangnya, si penjamin tersebutlah yang akan melaksanakan atau mengambil alih kewajiban tersebut, Jadi, jika bank yang menjadi penjaminnya, maka banklah yang akan melaksanakan atau mengambil alih kewajiban tersebut, yang lazimnya adalah pembayaran ganti rugi. Di dalam menjalankan fungsi-fungsinya bank dapat memberikan jasa-jasa pemberian bank garansi, sepanjang tidak bertentangan atau melanggar peraturan perundang-undangan yang berlaku. Bahkan, pemberian bank garansi ini dapat dijadikan suatu produk jasa perbankan yang berpotensi menguntungkan bagi bank dalam bentuk fee. Pemberian garansi saat ini sudah merupakan bisnis rutin dari bank, ditengah maraknya upaya percepatan pembangunan infrastruktur saat ini, dimana dalam proses tersebut bank akan mendapatkan provisi yang mana dihitung dari persentase tertentu dari jumlah proyek yang digaransikan itu. Jadi, bagi bank produk bank garansi secara tidak langsung telah menjadi salah satu sumber income yang bersifat fee based. Namun demikian, sebagaimana yang dipahami bahwa bisnis bank sangatlah konservatif. Dalam arti bank tidak boleh melakukan bisnis yang mengandung unsur spekulatifnya tinggi, sehingga dalam pemberian bank garansi haruslah memenuhi prinsip kehatihatian bank (prudental banking). Berdasarkan Surat Keputusan Direksi Bank Indonesia Nomor 23/88/KEP/DIR tanggal 18 Maret 1991 tentang Pemberian Garansi oleh Bank, dapat dipahami bahwa bank memberikan suatu jaminan dalam bentuk bank garansi yang antara lain adalah sebagai berikut: Pertama. Garansi dalam bentuk warkat yang diterbitkan oleh bank yang mengakibatkan kewajiban membayar terhadap pihak yang menerima garansi apabila pihak yang dijamin tersebut wanprestasi, Kedua. Garansi dalam bentuk penandatanganan kedua dan seterusnya atas surat-surat berharga, yang diikuti dengan hak regres yang dapat menimbulkan kewajiban membayar bagi bank apabila pihak yang dijamin terbukti wanprestasi. Ketiga. garansi lainnya yang terjadi karena perjanjian bersyarat sehingga dapat menimbulkan kewajiban finansial bagi . Adapun mengenai hak dan kewajiban yang muncul ketika diterbitkannya bank garansi oleh suatu bank antara lain adalah, dapat digambarkan sebagai berikut: Pertama : Seseorang atau badan usaha memperoleh kesempatan untuk mengerjakan suatu proyek yang diberikan oleh suatu lembaga atau instansi pemerintah atau swasta (bouwheer), baik dengan penunjukkan langsung ataupun dengan tender yang dimenangkan olehnya. Salah satu syarat yang harus dipenuhi oleh pelaksana kerja tersebut adalah adanya garansi dari bank atau perusahaan asuransi tertentu. Kedua : Seseorang atau badan usaha (pelaksana kerja) tersebut mengajukan permohonan bank garansi kepada salah satu bank (biasanya yang selama ini terjadi adalah kepada bank yang telah menjadi krediturnya). Ketiga : Setelah melalui berbagai proses (prosesnya seperti pemberian kredit pada umumnya) bank setuju untuk memberikan atau menerbitkan bank garansi. Keempat : Oleh karena fasilitas bank garansi ini sewaktu-waktu dapat saja diklaim dan bank harus membayar ganti rugi kepada bouwheer, maka dibuatkanlah suatu perjanjian pemberian bank garansi dan pemberian jaminan oleh nasabah yang bersangkutan. Dalam pemberian bank garansi, bank bertindak sebagai penanggung atau penjamin akan mengandung risiko, maka dalam menerbitkan atau mengeluarkan bank garansi, bank akan meminta kontra garansi atau jaminan lawan (counter guarantee) kepada dijamin yang dapat berupa uang tunai, deposito, simpanan giro, surat-surat 
berharga, maupun harta kekayaan [3].

Dalam surat edaran bank Indonesia Nomor 23/UKU tanggal 19 Maret 1991 perihal pemberian Garansi oleh Bank, telah disebutkan bahwa Burgerlijk Wetboek atau BW hanya mengatur masalah penanggungan hutang secara umum, yang dalam hal ini adalah akibat-akibat hukum yang timbul karena penanggungan hutang, sedangkan ketentuan mengenai bentuk maupun syarat-syarat minimum yang harus dimuat dalam warkat/perjanjian tidak diatur secara lengkap. Oleh karena itu, supaya bank mempunyai pedoma, yang dapat digunakan sebagai guidelines dalam pelaksanaan pemberian suatu bank garansi, maka dalam pemberian bank garansi perlu ditetapkannya syarat-syarat minimum yang harus dipenuhi, yang dalamhal ini suatu bank garansi sekurang-kurangnya harus memuat: Pertama. Judul "bank Garansi” atau “Garansi Bank” Dalam hal bank mengeluarkan bank garansi dalam bahasa asing, maka di bawah judul dalam bahasa asing yang dikehendaki tersebut diberi judul dalam kurung "bank Garansi” atau “Garansi Bank” Kedua. Nama dan alamat bank pemberi bank garansi Ketiga. Tanggal penerbitan bank garansi Keempat. Transaksi antara pihak yang dijamin dengan penerima jaminan Kelima. Jumlah uang yang dijamin oleh Bank, Keenam. Tanggal mulai berlaku dan berakhirnya Bank Garansi Mengingat bank garansi merupakan perjanjian buntut / tambahan (accesoire) maka jangka waktunya akan berakhir selain karena berakhirnya perjanjian pokok, juga karena berakhirnya bank garansi sebagaimana ditetapkan dalam bank garansi yang bersangkutan. Ketujuh. Penegasan batas waktu pengajuan klaim. Dalam hubungan ini untuk memperoleh keseragaman hendaknya dengan jelas mencantumkan dalam bank garansi bahwa klaim dapat diajukan segera setelah timbul wanprestasi dengan batas waktu pengajuan terakhir sekurangkurangnya 14 (empat belas) hari dan selambat-lambatnya 30 (tiga puluh) hari setelah berakhirnya bank garansi tersebut. Kedelapan. Menurut Pasal 1831 KUH Perdata, apabila timbul cidera janji (wanprestasi), sebelum melakukan pembayaran si penjamin (bank dapat meminta agar benda-benda si berhutang disita dan dijual terlebih dahulu untuk melunasi hutangnya. Dalam pada itu, menurut Pasal 1832 KUH Perdata, dapat diperjanjikan bank melepaskan hak istimewanya sebagaimana dimaksud dalam Pasal 1831 KUH perdata, yaitu meminta terlebih dahulu agar bendabenda si berhutang disita dan dijual untuk melunasi hutangnya, sehingga berarti dalam hal dipilih ketentuan Pasal 1832 KUH Perdata, maka bank wajib membayar bank garansi yang bersangkutan segera setelah timbul cidera janji (wanprestasi) dan menerima tuntutan pemenuhan kewajiban (claim). Agar pihak yang dijamin maupun pihak yang menerima garansi dapat mengetahui dengan jelas ketentuan Pasal 1831 atau Pasal 1832 KUH Perdata yang akan dipergunakan, maka bank diwajibkan memperjanjikan dan mencantumkan ketentuan yang dipilihnya dalam bank garansi yang bersangkutan.

Selanjutnya untuk meminimalisir potensi risiko dalam penerbitan garansi bank, pihak bank dapat pula mensyaratkan adanya jaminan lawan (counter garanty) yang nilainya ditentukan oleh kebijakan bank namun biasanya setara dengan nilai jaminan yang tercantum dalam garansi bank Jaminan lawan tersebut tidak diwajibkan dalam bentuk uang tunai, namun dapat berbentuk giro, deposito, surat-surat berharga, atau dokumen lain yang dianggap aman oleh bank.

2. Kafalah

Pada dasarnya kafalah ini bermakna penjaminan, hal ini dikarenakan bank selaku kafil atau penjamin bagi pihak ketiga, dalam bentuk pembiayaan kafalah, bank dapat bertindak selaku penjamin bagi pihak investor yang ingin melakukan kontrak kerjasama dengan pemerintah, jaminan dari bank sebagaimana halnya dalam bank garansi amatlah diperlukan bagi investor supaya dapat memperoleh kepercayaan dari pemerintah sehingga Public Private Partnership (PPP) dapat terlaksana, pembiayaan kafalah adalah suatu kebolehan dalam kegaitan bisnis Islam mengingat kaidah utama dari muamalah adalah "segala sesuatu dalam bermuamalah diperbolehkan selama tidak ada dalil yang melarangnya”, berdasarkan kaidah pokok muamalah tersebut dapat dipahami bahwa hukum Islam khususnya dalam bidang ekonomi mengarahkan perilaku individu dan masyarakat ke arah suatu upaya pemenuhan kebutuhan-kebutuhan dalam kegiatan bisnis dengan menggunakan sumberdaya yang telah tersedia. Sehingga dapat dipahami bahwa bisnis Islam dijalankan menggunakan beberapa prinsip yang antara lain adalah :

a. Berbagai jenis sumber daya dipandang sebagai pemberian atau titipan Allah yang harus dimanfaatkan seefesien dan seoptimal mungkin dalam produksi guna memenui kesejahteraan bersama, untuk dirinya dan orang lain. Kegiatan itu akan dipertanggung jawabkan di akhirat.

b. Hukum Islam mengakui kepemilian pribadi (hak milik) dalam batas-batas tertentu termasuk kepemilian alat produksi dan faktor produksi.।

c. Kekuatan utama bidang ekonomi ialah kerja sama antara para pihak dalam kontrak.

d. Pemilikan kekayaan pribadi harus berperan sebagai kapital produktif yang akan meningkatkan besaran produk nasional dan kesejahteraan masyarakat. Pemelikan kekayaan tidak boleh terakumulasi dan dikuasai oleh beberapa orang saja. 
e. Hukum Islam menjamin kepemilikan masyarakat dan penggunaanya direncanakan untuk kepentingan orang banyak.

f. Hukum Islam mencela keuntungan yang berlebihan, perdagangan yang tidak jujur, perlakuan yang tidak adil, diskriminasi dan penindasan.

g. Kewajiban membayar Zakat.

h. Islam melarang riba [3]

Kafalah dalam penggunaan sumber daya yang tersedia melalui mekanisme Public Private Partnerships (PPP) amatlah penting, karena untuk memaksimalkan potensi penggunaan sumber daya tersebut tidak jarang dibutuhkan modal yang besar dan dapat menimbulkan potensi risiko yang tinggi, ada dua aspek yaitu positif dan negatif, secara positif bank syariah dapat mengatasi permodalan dan secara negatif bank dapat menilai potensi risiko sehingga risiko tersebut tidak muncul ketika Public Private Partnerships (PPP) dilaksanakan. Untuk menjamin kelancaran pelaksanaan Public Private Partnerships (PPP) bank syariah dapat memberikan kafalan muallaqah, yaitu jaminan mutlak yang dibatasi oleh tujuan tertentu dan untuk suatu tujuan tertentu pula yang dalam hal ini adalah pelaksanaan proyek yang telah diperjanjikan dalam Public Private Partnerships (PPP) yang dibuat oleh investor dan pemerintah suatu negara.

Sama halnya dengan perbankan konvensional,banks syariah juga mengenal manajemen risiko dan mengenal penerapan prinsip kehati-hatian, adapun mengenai pengaplikasian manajemen risiko ini dapat dilihat pada pandangan Vernados yang menyatakan:

"investment risk is the most critical operational risk affecting banks operating according to a paradigm version of Islamic banking because it is inherent in their core activities, namely those involving PLS modes of financing. Errico and Farahbaksh state that the assessment and management of investmen risk is more difficult in an Islamic environment than in conventional banking. In order to safeguard invested funds and realise profits, Islamic banks are more dependent than conventional banks on the existence of an adequate and appropriate set of policies and infrastructure for portfolio diversification, monitoring and control. They also need a sufficient supply of trained banking staff skilled in investment and Islamic banking practices to implement these policies. Unfortunately, as the experiences of other developing and transition economics indicate, appropriate policies and infrastructure for riskmanagement and human technical expertise are difficult to establish and require a considerable amount of time to develop. The regulatory framework for banking supervision should therefore be designed to specifically address these issues" [4].

Adapun penerapan manajemen risiko dalam mendukung suatu investasi bertujuan untuk mencegah adanya potensi risiko yang dapat menyebabkan suatu bank colaps, sehingga apabila ada suatu kondisi yang menyebabkan suatu investasi tidak diberikan dukungan dalam bentuk jaminan dalam suatu Public Private Partnerships (PPP) bukan berarti bank enggan atau tidak mau berkeinginan untuk mendukung percepatan pembangunan infrastruktur ataupun bukan berarti bank tidak mendukung program pemerintah dan bukan pula berarti bank tidak mendukung iklim pertumbuhan investasi, namun lebih daripada itu bank melihat adanya potensi risiko yang cukup signifikan yang dapat menyebabkan bank mengalami kerugian apabila tetap memaksakan kebijakan untuk memberikan jaminan dalam suatu pelaksanaan Public Private Partnerships (PPP).

\section{Kesimpulan}

Public Private Partnerships (PPP), merupakan salah satu upaya yang dapat dilakukan untuk mempercepat pembangunan infrastruktur di tanah air, campur tangan swasta atau investor dalam kegiatan ini adalah mutlak diperlukan, emgningat keterbatasan modal, sumber daya dan permodalan maka bentuk kerjasama ini adalah jalan keluar yang terbaik. Akan tetapi ketika menjalankan Public Private Partnerships (PPP) ada beberapa hal yang perlu untuk diperhatikan bahwa investor ketika akan melakukan suatu investasi tentu yang menjadi parameter utama adalah keuntungan, hal menjadi prioritas utama dalam kegiatan investasi apapun baik dalam Public Private Partnerships (PPP) ataupun dalam bentuk kerjasama yang lain. Hal ini adalah wajar karena dalam teori ekonomi keuntungan adalah katalisator pemicu pergerakan kegiatan ekonomi yang berkelanjutan (suistainable economic system), untuk menjamin proses tersebut berjalan sempurna tentu perlu diberikan payung hukum yang memadai, sehingga proses tersebut tidak hanya dapat mendatangkan keuntungan yang seimbang bagi para pihak namun juga dapat dipastikan tidak bertentangan dengan norma. Perlunya perlindungan hukum ini selain tidak akan menimbulkan kerugian bagi negara dan rakyat namun juga dapat menarik investor lain untuk melakukan investasi jangka panjang yang tentu saja hal ini tidak hanya memberikan keuntungan bagi investor namun juga bagi negara dan secara tidak langusng juga dapat memberikan keuntungan bagi rakyat secara keseluruhan. Konstitusi telah mewujudkan negara utnuk senantiasa berusaha mewujudkan kesejahteraan rakyat tanpa terkecuali, negara dituntut untuk tidak egois dalam mencari keuntungan, yang dalam arti luas keuntungan tersebut tidak hanya bagi segelintir pihak atau bagi pihak tertentu namun harus mendtangkan keuntungan bagi seluruh rakyat Indonesia.

Mengenai bentuk penjaminan yang dapat dilakukan industri perbankan terhadap pelaksanaan Public Private Partnerships (PPP) ada beberapa bentuk yang dpat digunakan yang antara lain adalah Pertama, Bid Bond Bid Bond 
yaitu bank garansi yang diterbitkan oleh bank bagi nasabahnya agar dapat mengikuti tender / penawaran atas suatu proyek. Bank garansi jenis ini diberikan kepada nasabah bank yang akan mengikuti penawaran atau tender untuk pengerjaan suatu proyek yang disyaratkan adanya suatu jaminan penawaran yang dikeluarkan oleh bank. Terjadi cidera janji (wanprestasi) apabila pihak dijain (nasabah bank) tidak menerima penunjukan untuk melaksanakan proyek, padahal ia sudah dinyatakan sebagai pemenangnya oleh bouwheer atau pihak yang dijamin atau pemberi proyek. Kedua, Performance Bond Performance bond yaitu bank garansi yang diterbitkan oleh bank untuk menjamin kepastian (mutu dan ketepatan) pengerjaan suatu proyek atau untuk menjamin performance salah satu pihak dalam suatu transaksi. Terjadi cidera janji (wanprestasi) apabila pihak dijamin (nasabah bank) tidak melakukan pekerjaannya sesuai dengan mutu yang telah diperjanjikan atau mengalami keterlambatan dalam penyelesaiannya. Ketiga, (Advance) Payment Bond (Advance) payment bond, yaitu bank garansi yang diterbitkan oleh bank untuk menjamin pembayaran yang (terlebih dahulu) telah diterima oleh pemohon bank garansi dari pemilik proyek (bouwheer) atau pemberi order, baik dalam bentuk uang muka, pembayaran termin, maupun keseluruhan nilai proyek. Terjadi cidera janji (wanprestasi) apabila pihak dijamin (nasabah bank) tidak melaksanakan kewajibannya untuk melaksanakan atau mengerjakan proyek yang telah diberikannya, padahal ia telah meneirma pembayaran di muka atas proyek tersebut dari bouwheer atau pihak yang dijamin pemberi kerja (proyek), dan yang terakhir adalah, Jaminan Pemeliharaan (Maintenance Bond) Pada waktu penyerahan pertama atau pekerjaan telah mencapai 100\% rekanan baru menerima pembayaran 95\% dari nilai kontrak, sedangkan sisanya sebesar 5\% masih ditahan pimpinan proyek dengan maksud agar rekaman dalam masa pemeliharaan wajib melaksanakan perbaikan-perbaikan terhadap kekurangan dari pekerjaan. Kesemua bentuk penjaminan bank tersbeut pada daarnya dpat diberikan oleh industri bank konvensional melalui produk bank garansi ataupun bank syariah melalui bentuk pembiayaan kafalah, yang mana kesemua bentuk pembiayaan tersebut mempunyai satu kesamaan yaitu bank selaku penjamin bahwa investor tidak akan melalaikan kewajibannya kepada pemerintah dalam pelaksanaan Public Private Partnerships (PPP).

Melalui potensi sumber daya alam dan potensi geografis serta demofrafis, Indonesia merupakan arena baru bagi para investor untuk menanamkan modalnya, kesemua potensi tersebut secara tidak langsung menjadi minat tersendiri bagi investor, betapa tidak dengan sumberdaya yang melimpah, letak geografis yang strategis dan peluang demografis yang cukup signifikan menjadikan Indonesia sebagai pilihan ideal. Pemerintah mempunyai semua keunggulan tersebut dan investor mempunyai keunggulan yaitu permodalan dan inovasi. Perkembangan teknologi dan inovasi telah membuktikan bahwa sektor swasta mempunyai perkembangan inovasi yang lebih maju apabila dibandingkan sektor pemerintah. Revolusi teknologi adalah sesuatu yang tidak bisa dihalangi, dibatasi atau dihentikan sama sekali, proses ini akan tersu berjalan seiring dengan perekembangan yang ada pada masyarakat itu sendiri, disinilah dibutuhkan adanya peran serta dari pemerintah untuk mengakomodir proses tersebut sehingga dapat memberikan keuntungan bagi seluruh rakyat tanpa terkecuali, dalam hal ini kepentingan para pihak akan bermain, di satu sisi pemerintah ingin memberikan yang terbaik bagi rakyatnya melalui kemajuan dan inovasi teknologi terkini yang diwujudkan dalam pembangunan infrastruktur, di lain sisi pihak swasta ingin mendapatkan keuntungan melalui investasi modal dan teknologi yang dimilikinya. Disinilah pemerintah harus jeli untuk mengambil peluang ini, pemerintah harus memastikan kepentingannya terpenuhi bersamaan dengan pemeuhan kepentingan investor, apabila hal ini terwujud maka akan menciptakan iklim investasi yang kondusif yang bermanfaat bagi rakyat Indonesia dan secara tidak langsung pemerintah telah mewujudkan amanat konstitusi yaitu mensejahterakan kehidupan berbangsa dan bernegara.

\section{References}

[1] Y. A. Rahman, The Art of Islamic Banking and Finance, Tools and Technique for Community-Based Banking. John Wiley \& Sons Inc, 2010.

[2] H. Van Greuning and Z. Iqbal, Risk Analysis for Islamic Banks. Washington DC: The World Bank , 2008.

[3] Z. Arifin, “Mekanisme Kerja Perbankan Islam dan Permasalahannya,” J. Huk. Bisnis, vol. 11, 2000.

[4] A. M. Venardos, Islamic Banking and Finance in South-East Asia, vol. 3. WORLD SCIENTIFIC, 2006. 